\title{
Scent Marking Behaviour and Social Organization in the Indian Soft-furred Field-rat
}

\author{
Mohammed IDRIS \& Ishwar PRAKASH
}

\begin{abstract}
Idris = M. \& Prakash I., 1987: Scent marking behaviour and social organization in the Indian soft-furred field-rat. Acta theriol., 32, 19: 315-325, [With 3 Tables \& 1 Fig.]

Social behaviour of soft-furred field-rat. Rattus meltada pallidior (Ryley, 1914) was studied in seminatural condition of a large rattery $(13 \times 7 \mathrm{~m})$. Hourly observations, continued for 30 evenings, revealed that the male metads were more active and performed all the aggressive acts like fighting and chasing at a significantly higher frequency than the females. But dominant females were found to be as aggressive as the dominant males, indicating that social organisation of metads is based on multi-dominance of animals of both sexes. The metads deposit two types of scent in the area of their movement: that of the sebum of the mid abdominal gland (only males) and of urine. The former activity is performed by the dominant males only but all females mark with urine and the dominant ones do so at a higher frequency. It is revealed that the scent marking and urine marking have an important role in displaying the dominant status of the animals in the territory and in reproduction of metads.

[Cordinating \& Monitoring Centre for Rodent Research and Training, Central Arid Zone Research Institute, Jodhpur 342 003, India]
\end{abstract}

\section{INTRODUCTION}

One of the species among the Indian rodents which can multiply to create an upsurge of numbers in the population (Millard, 1920) is the metad or the soft-fured field-rat, Rattus meltada (Gray, 1937). It is fairly abundant in crop fields all over the Indian subcontinent but also occurs in grasslands and forests. In the desert region, it constitutes 13 per cent of the rodent population in the sandy habitat and 20 per cent in crop fields and village complex (Prakash, 1975). It is a serious pest of rainfed as well as irrigated crops (Rana \& Prakash, 1980). This nocturnal rodent lives singly or in pairs in burrows or in cracks in the mud (Barnett \& Prakash, 1975) and moves on pathways which are clearly visible in the grasslands and in the vicinity of crop fields. Some work has been carried out on its ecology (Rana \& Prakash, 1984; Rana, 1985), breeding biology (Rana \& Prakash, 1984) but very little is known about its social and scent marking behaviour.

The male metads possess a fairly large $\left(160.83 \pm 19.88 \mathrm{~mm}^{2}\right)$ midabdominal scent marking gland (Prakash \& Kumari, 1979) with which 
it scent marks the general area of its home range, particularly the burrow openings and the pathways which it follows for its nocturnal sojourns. In addition, scent marking is also performed by animals of both sexes with urine (Prakash \& Idris, 1982). To study the social and scent marking behaviour of metads, we maintained their cclony under semi natural conditions and observed them for about a month. The results of our cbservations are presented in this communication.

\section{METHODS}

The metads, Rattus meltada pallidior (Ryley, 1914) were trapped from grasslands at Bisalpur $\left(25^{\circ} 7 \mathrm{~N}-73^{\circ} 10^{\prime} \mathrm{E}\right)$, from the foot hills of Aravalli ranges in western Rajasthan, India. They were acclimatised in individual cages $(90 \times 30 \times 30 \mathrm{~cm})$ for 6 days. During this period their sebum and urine marking frequency were recorded for 1 hour per evening. Two smooth objects, clean stones, were placed in the laboratory cages to facilitate observations on scent marking. Thereafter 6 male and 6 female metads were released in a rattery $(13 \times 7 \mathrm{~m})$ after hair clipping (Fitzwater \& Prakash, 1978) for individual identification. The oval rattery space was marked into $1 \mathrm{~m}^{2}$ quadrats by installing numbered pegs in a grid pattern. During observation period the locations of every metad in the rattery were plotted on a graph paper for reconstructing their ranges of movement. Behaviour of rodents was observed for 30 days, one hour every evening ( 7 to $8 \mathrm{pm}$ ) under dim red light during winter season (December). The frequency and duration of various behavioural acts (Table 1) were recorded for every rodent. Food and drinking water were provided ad libitum at two points in the rattery (Fig. 1).

Table 1

Mean frequency $( \pm \mathrm{SE}$ ) of behavioural acts per rodent per hour in Rattus meltada pallidior.

\begin{tabular}{lrr}
\hline Kind of activity & \multicolumn{1}{c}{ Males } & \multicolumn{1}{c}{ Females } \\
\hline $\begin{array}{l}\text { Burrow visits } \\
\text { Visits to food containers }\end{array}$ & $10.63 \pm 0.69$ & $8.90 \pm 0.19$ \\
$\begin{array}{l}\text { Duration at food containers } \\
\text { (seconds) }\end{array}$ & $1.11 \pm 0.15$ & $0.94 \pm 0.05$ \\
Visits to water container & $0.49 \pm 0.02$ & $113.90 \pm 5.71$ \\
Duration at water container & $30.49 \pm 2.07$ & $0.59 \pm 0.02$ \\
(seconds) & $2.11 \pm 0.86$ & $36.93 \pm 2.71$ \\
Sebum marking & - & - \\
Urine marking & & $2.38 \pm 0.51$ \\
\hline
\end{tabular}

\section{RESULTS}

\subsection{Activity}

After release in the rattery, the metads patrolled and explored the entire area for scme time and then started digging burrows. Intermittently, the animals were engaged in sniffing and following each other. 
$A$
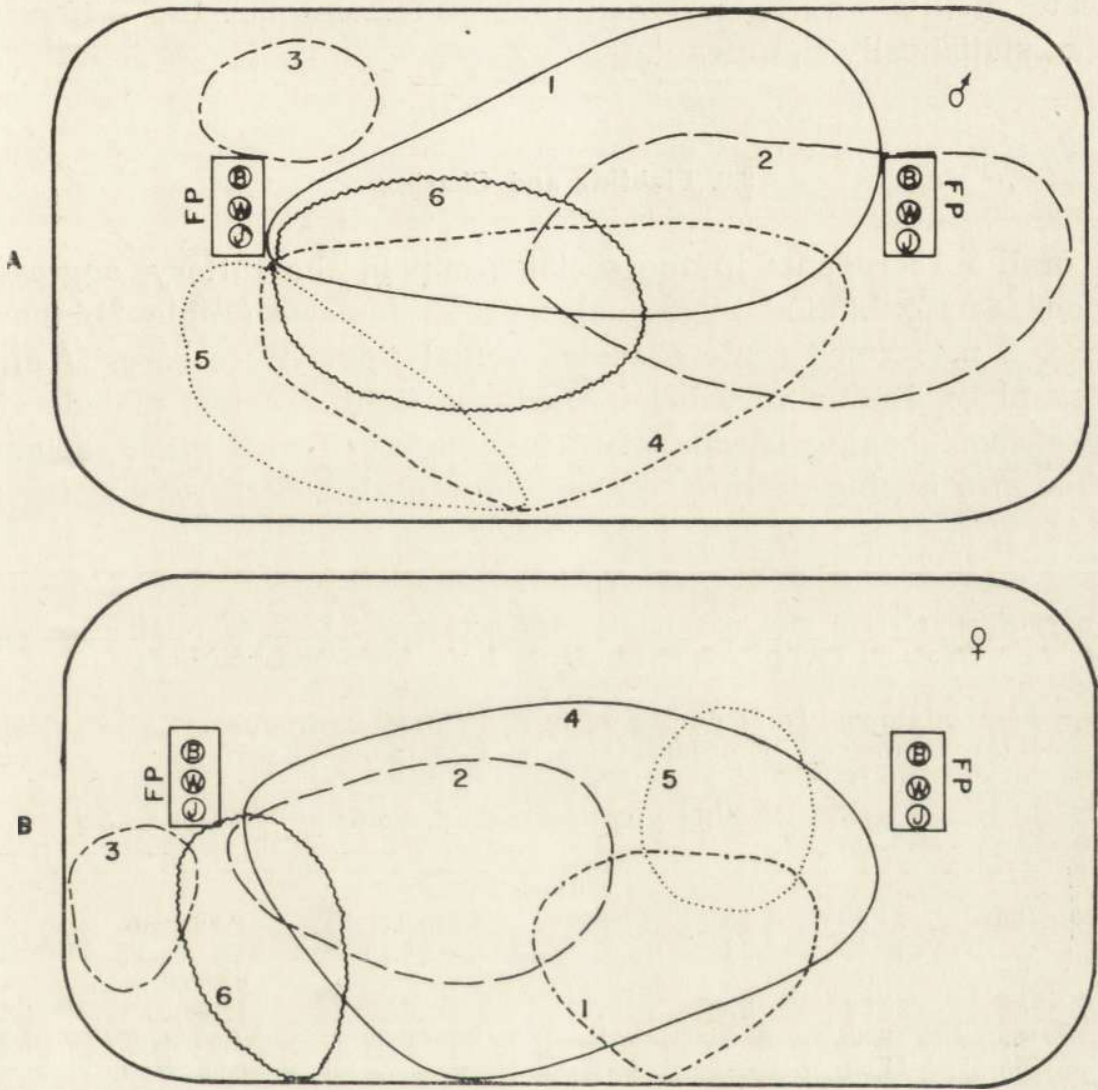

Fig. 1. Range of movement of six males (A) and six females (B) Rattus meltada pallidior in the rattery. ( $\mathrm{FP}=$ Feeding and drinking platform; $\mathrm{B}=\mathrm{Bajra}$, Pennisetum typhoides; $\mathrm{J}=\mathrm{Jowar}$, Sorqhum vulgare; $\mathrm{W}=\mathrm{Water})$.

When two strange males encountered each other for the first time, fight was not always observed; rather, after a naso-nasal or naso-anal contact, the smaller one by body weight exhibited a submissive posture, with withdrawn ears, half-closed eyes and it tried to avoid the bigger metad in an half-curling or lying-down posture. The smaller ones usually moved away from the path of the heavy-weight metad after a naso-nasal contact. A few rodents scent marked frequently. The number of burrow openings increased from 16 to 26 during the observation period. The individuals appeared to restrict their movement to areas of their "beat". A few even moved on a "pathway" as they are used to move on definite paths in nature.

On an overall basis the male metads were found to be more active than the females (Table 1). The frequency of their visits to burrows and 
to water containers was higher and the duration of their stay at food and water points was longer than that of females but the differences were not statistically significant.

\subsection{Fighting and Chasing}

Out of the 12 rodents in the social group in the rattery, aggressive behaviour was exhibited by 3 males and 3 females (Table 2), though male No. 5 performed some chasing. Actual fights were rare. If at all one took place, it was very brief. During a fight, the two metads after having a short boxing session start jumping over each other, awaiting the other in a boxing posture, maintaining an alert posture, keeping the

Table 2

Frequency of aggressive and communicatory acts (mean $\pm \mathrm{SE}$ ) in relation to social ranks and size of home ranges of Rattus meltada pallidior.

\begin{tabular}{|c|c|c|c|c|c|c|c|}
\hline \multirow[t]{2}{*}{$\begin{array}{l}\text { Rodent } \\
\text { No. }\end{array}$} & \multirow[t]{2}{*}{$\begin{array}{l}\text { Body } \\
\text { wt.(g) }\end{array}$} & \multirow{2}{*}{$\begin{array}{l}\text { Home } \\
\text { range } \\
\left(\mathrm{m}^{2}\right)\end{array}$} & \multicolumn{2}{|c|}{$\begin{array}{l}\text { Total during } 30 \mathrm{hrs} \\
\text { of observations }\end{array}$} & \multicolumn{2}{|c|}{$\begin{array}{l}\text { Mean frequency } \\
\text { per metad per hour }\end{array}$} & \multirow[t]{2}{*}{$\begin{array}{l}\text { Social } \\
\text { rank }\end{array}$} \\
\hline & & & Chasing & Fighting $\mathrm{S}$ & Sebum marking & Urine marking & \\
\hline & \multicolumn{6}{|c|}{ Males } & \\
\hline 1 & 90 & 21.95 & 35 & 15 & $3.64 \pm 0.32$ & $2.50 \pm 0.64$ & I \\
\hline 2 & 82 & 18.45 & 23 & 10 & $2.44 \pm 0.40$ & $1.93 \pm 0.33$ & III \\
\hline 3 & 70 & 3.01 & - & - & - & $0.66 \pm 0.19$ & - \\
\hline 4 & 80 & 20.69 & 27 & 13 & $5.30 \pm 0.59$ & $1.40 \pm 0.29$ & II \\
\hline 5 & 65 & 8.30 & 3 & - & $1.30 \pm 0.30$ & $1.00 \pm 0.22$ & VII \\
\hline \multirow[t]{2}{*}{6} & 55 & 11.82 & - & - & - & $0.50 \pm 0.10$ & - \\
\hline & \multicolumn{6}{|c|}{ Females } & \\
\hline 1 & 86 & 8.13 & 19 & 10 & - & $4.06 \pm 0.31$ & IV \\
\hline 2 & 70 & 11.31 & 21 & 5 & - & $3.76 \pm 0.36$ & V \\
\hline 3 & 50 & 2.87 & - & - & - & $0.93 \pm 0.24$ & - \\
\hline & 55 & 30.44 & - & - & - & $1.56 \pm 0.27$ & - \\
\hline 5 & 78 & 4.98 & 13 & 6 & - & $2.26 \pm 0.27$ & VI \\
\hline 6 & 72 & 5.79 & - & - & - & $1.68 \pm 0.27$ & - \\
\hline
\end{tabular}

ears cocked up. Very soon one of them, the submissive one, presented its back in a half curled posture and the dominant one sniffed and sometimes mounted it. Biting was never observed. The encounter mostly ended without any damage to the two animals.

The male metads were involved in more number of fights (Chisquare $\left._{(1)}=4.8, \quad p<0.05\right)$ and chasing $\left(\right.$ Chi-square $\left.{ }_{(1)}=8.68, \quad p<0.001\right)$ than the females. The act of chasing the other conspecifics was significantly more frequent in male (Chi-square ${ }_{(1)}=19.8, p<0.001$ ) as well as in female metads (Chi-square ${ }_{(1)}=13.8, p<0.001$ ) than the act of actual fighting. On the basis of the frequency of these acts, a dominance 
score was allotted to the metads. Males ranked higher than the females in social hierarchy (Table 2). Generally speaking, heavier rodents occupied superior dominance status (Table 2). From the number of metads involved in aggressive acts, it appears that their sccial system is based on the dominance of a number of males and females and the group is not monopolised by a single male or a female or by a pair.

\subsection{Sebum Marking}

Since only the male metads possess the mid abdominal scent marking gland, they mark with sebum the general substratum and protruding objects. Whereas all males in individual cages marked with sebum on an average 18.5 times per hour, this act was performed only by four males out of six after releasing them in the rattery, and the marking activity was reduced to 2.11 times per hour (Table 1). The two animals of lower body weight did not participate in this activity at all. Incidentally these are the animals which do not fare in the dominance hierarchy (Table 2).

\subsection{Urine Marking}

Urine marking is performed by male as well as female metads, but at a higher frequency by the females (Table 1). It appears that through their higher urine marking frequency, the females, which are devoid of scent marking gland, create unisex odours to a level as that of males.

Table 3

Reduction of scent marking frequency in Rattus meltada pallidior after the solitary individuals were grouped together.

\begin{tabular}{|c|c|c|c|c|}
\hline \multirow{3}{*}{ Environments } & \multicolumn{4}{|c|}{ Frequency (mean \pm S.E per hour) } \\
\hline & \multicolumn{2}{|c|}{ Sebum marking } & \multicolumn{2}{|c|}{ Urine marking } \\
\hline & substratum & objects & substratum & objects \\
\hline \multirow{4}{*}{$\begin{array}{l}\text { Lab-cage } \\
\text { (solitary) } \\
\text { Rattery } \\
\text { (in group) }\end{array}$} & & Males & & \\
\hline & $5.1 \pm 0.91$ & $13.33 \pm 2.13$ & $2.83 \pm 0.87$ & $5.83 \pm 1.31$ \\
\hline & $1.60 \pm 0.83 *$ & $3.00 \pm 1.20 * *$ & $0.83 \pm 0.44 *$ & $1.66 \pm 0.83 *$ \\
\hline & & Females & & \\
\hline \multirow{2}{*}{$\begin{array}{l}\text { Lab-cage } \\
\text { (solitary) } \\
\text { Rattery } \\
\text { (in group) }\end{array}$} & -.. & - & $3.00 \pm 0.85$ & $8.66 \pm 1.50$ \\
\hline & - & - & $0.83 \pm 0.44 *$ & $3.16 \pm 1.24 *$ \\
\hline
\end{tabular}

Level of significance between two environments: (Student's $t$ test) ** $-p<0.001,{ }^{*}-p<0.05$. 
Unlike sebum marking in males, urine marking is performed by all females, though the frequency of this activity is much higher in the dominant ones (Table 2). However, a definite trend was not observed to indicate a relationship between the body weight of individual females and the frequency of their urine marking. This activity also declined significantly $(p<0.05)$ in metads of both the sexes when they were grouped together (Table 3 ).

\subsection{Movement}

It was observed that the mean home ranges of male metads $\left(14.0 \mathrm{~m}^{2} \pm\right.$ \pm 2.81 , Fig. 1a) are larger than that of females $\left(10.58 \mathrm{~m}^{2} \pm 3.78\right.$, Fig. 1b). Overlapping of the home ranges of nearly all males and females suggests that they are "contact" animals. However, the ranges of male No. 3 (Fig. 1a) and females No. 3 and 5 (Fig. 1b) are more or less exclusive. It is noteworthy to point out that these isolated metads are the animals which figure very low in the dominance hierarchy (Table 2). The correction coefficients between body weight of male and female metads and their home range sizes were not found to be statistically significant.

\section{DISCUSSION}

The observations have provided a number of clues to understand the scent marking behaviour and social organisation of metads. It has been found that they are fairly less agile in their activity as compared to the two gerbils like Tatera indica or Meriones hurrianae. As a consequence, their visits to the burrow and their range of movements are considerably smaller than that of the two mentioned gerbils. Their fights (male $X$ $\times$ male or female $X$ female) last only for a few seconds and are not as vigorous as those in other rodents studied (Kumari \& Prakash, 1981; Idris \& Prakash, 1985). In fact, the individual metads in the rattery avoided each other, maintained a distance and, therefore, the chances of skirmish were minimal. However, the male metads were involved in social organisation is based on "multi-domiance" of animals of both (1963), at more number of occasions than the females (Table 2).

Our observations, that only three males and three females, out of 12 rodents, were involved in aggressive acts (Table 2) suggest that their sccial organisation is based on "multi-dominance" of animals of both the sexes. The social organisation of Rattus m. pallidior, it appears, is more like that of Tatera indica which is based on multi dominance of both male and female rodents (Idris \& Prakash, 1985) and differs from that of Meriones hurrianae in which one or two males and only a single 
female dominate the social group (Kumari \& Prakash, 1981). According to the classification of Eisenberg (1963) the social organisation of Rattus meltada pallidior can be classified under "contact" and "pair tolerance" category, verging towards "group tolerance".

It is interesting that the frequency of scent marking activity (both by sebum and urine) is more in dominant rodents of the two sexes (Table 2). Scent marking by sebum of ventral marking gland is not performed by male metads of very low rank as it is monopolised by the dominant ones. However, all the animals of the two sexes urine mark in a social group, dominant ones at a higher rate.

It is interesting that the marking frequency of metads declined significantly after they were released in the rattery as a social group (Table 3). Similar observations were made for the desert gerbil, Meriones hurrianae (Kumari \& Prakash, 1984) and in the Indian gerbil, Tatera indica indica (Idris \& Prakash, 1987) that frequency of scent marking significantly declines with increasing population density. It has been argued, as the density increased per unit area, the need for olfactory communication declines since the two gerbils are sparsely distributed in the desert grasslands and possibly there is a greater role of olfactory communication, but when they are grouped in relatively higher density, the intraspecific communication may be carried out by direct contact, visual and/or auditory means - rather than through olfactory cues. As a consequence, it is quite possible that the need for olfactory communication also declines in a social group. In the present study however, it was not the density of metads which may be responsible for the decline in scent marking activity but it is apparently the difference in their social structure; solitary and gregarious - a case similar to Tatera indica living in two type of social organisations (Prakash \& Idris 1982; Idris \& Prakash 1986). It is conjectured that the metads, like $T$. indica, become polygynous in a gregarious social life and, consequently find little use in depositing olfactory signals to attract mates. It, therefore, appears that odours of sebum of the mid-ventral scent marking gland and urine may have a role in reproduction of metads.

Acknowledgements: Gratitude is expressed to Dr. K. A. Shankarnarayan, Director of the Institute, for a strong support to our work. Thanks are due to colleagues for their assistance.

\section{REFERENCES}

1. Barnett S. A. \& Prakash I., 1975: Rodents of economic importance in India. Arnold Heinemann: 1-175, New Delhi.

2. Eibl-Eibesfeldt I., 1951: Gefangenschaftsbeobachtungen an der persischen Wusten- 
maus (Meriones persicus persicus Blanford): Ein Beitrag zur vergleichenden Ethologie der Nager. Z. Tierpsychol., 8: 400-423.

3. Eisenberg J. F., 1963: The behaviour of heteromyid rodents. Univ. Calif. Publ. Zool., 69: 1-100.

4. Fitzwater W. D. \& Prakash I., 1978: Handbook of vertebrate pest control. Indian Council of Agricultural Research: 1-92, New Delhi.

5. Idris M. \& Prakash I., 1982: Behavioural responses of the Indian gerbil, Tatera indica to conspecific sebum odour of the ventral scent marking gland. Proc. Indian Acad. Sci. (Anim. Sci.), 90: 259-265.

6. Idris M. \& Prakash I., 1985: Social and scent marking behaviour in Indian gerbil, Tatera indica. Biol. Behav., 10: 31-39.

7. Idris M. \& Prakash I., 1987: Scent marking activity in the Indian gerbil, T. indica in relation to population density. Anim. Behav., 35: 920-922.

8. Kumari S. \& Prakash I., 1981: Observations on the social behaviour of the Indian desert gerbil, Meriones hurrianae. Proc. Indian Acad. Sci. (Anim. Sci.), 90: $463-471$.

9. Millard W. S., 1920: Expected plague of field rats in 1920. J. Bombay nat. Hist. Soc., 27: 165-168.

10. Prakash I., 1975: Population ecology of rodents in the Rajasthan desert, India [In: "Rodents in desert environment", Eds. Prakash I. \& Ghosh P. K.]. Dr. Junk Publishers: 75-116. The Hague.

11. Prakash I. \& Idris M., 1982: Scent marking by female Indian gerbil, Tatera indica from two distinct desert habitats during oestrus. Indian J. exptl. biol., 20: $915-916$.

12. Prakash I. \& Kumari S., 1979: Occurrence of the ventral marking gland in Indian desert rodents. Säugetierk. Mitt., 27: 315-316.

13. Rana B. D., 1985: Ecological distribution of Rattus meltada pallidior J. Bombay nat. Hist. Soc., 72 (3): 573-580.

14. Rana B. D. \& Prakash I., 1980: The metad, a serious rodent pest of Indian agriculture. Indian Farming, 29 (10): 21-23.

15. Rana B. D. \& Prakash I., 1984: Reproduction biology of Rattus meltada pallidior (Ryley 1914) in the Rajasthan desert. J. Bombay nat. Hist. Soc., 81: 59-70.

Received 2 October 1986, Accepted 9 March 1987. 
Mohammed IDRIS i Ishwar PRAKASH

\section{ZNAKOWANIE TERENU I STRUKTURA SOCJALNA \\ U RATTUS MELTADA PALLIDIOR}

\section{Streszczenie}

Behawior socjalny indyjskiego gryzonia Rattus meltada pallidior (Ryley, 1914) badano w wolierach $13 \times 7 \mathrm{~m}$ w warunkach zbliżonych do naturalnych. Na podstawie godzinnych obserwacji, kontynuowanych w ciągu 30 wieczorów, ustalono, że samce $R$. meltada są bardziej aktywne i silniej przejawiają agresywne zachowania (walki, przeganianie) niż samice. Jednak samice dominujące są tak samo agresywne jak dominujące samce, co wskazuje, że osobniki obu płci mogą dominować w strukturze socjalnej populacji tego gatunku. Rattus meltada znakuje teren swej aktywności dwojako: wydzieliną zapachową z gruczolów brzusznych (tylko dominujące samce) i moczem (obie plcie). Dominujące samice znakują moczem częściej, niż pozostałe (Tabela 3). Oba rodzaje znakowania mają duże znaczenie w zachowaniach terytorialnych i reprodukcyjnych dominujących osobników Rattus meltada. 